\section{Weed Control and Organic Mulches Affect Physiology and Growth of Landscape Shrubs}

\author{
Bert M. Cregg ${ }^{1,2}$ \\ Michigan State University, Department of Horticulture and Department of \\ Forestry, A214 Plant and Soil Science, East Lansing, MI 48824 \\ Robert Schutzki ${ }^{1}$ \\ Michigan State University, Department of Horticulture, A218 Plant and Soil \\ Science, East Lansing, MI 48820
}

Additional index words. soil moisture, net photosynthesis, allelopathy, soil $\mathrm{pH}$, foliar nitrogen

Abstract. Landscape mulches are widely promoted to improve soil moisture retention, suppress weeds, and improve the growth of landscape plants. The objective of this project was to determine the effect of common landscape mulches (pine bark, hardwood fines, cypress mulch, color-enhanced ground pallets) on soil moisture, soil $\mathrm{pH}$, weed control, and physiology and growth of landscape shrubs. Two additional treatments were not mulched: no mulch + no weed control and no mulch + weed control. Growth was measured on eight taxa (Euonymus alatus 'Compactus', Spiraea $\times$ bumalda 'Goldflame', Weigela florida 'Java red', Taxus $\times$ media 'Runyan', Thuja occidentalis 'Golden Globe', Hydrangea paniculata 'Tardiva', Viburnum dentatum 'Synnestvedt', Viburnum trilobum 'Compactum'). Leaf gas exchange [net photosynthesis and stomatal conductance $\left(g_{\mathrm{s}}\right)$ ] were measured on Hydrangea paniculata, $V$. dentatum, and $V$. trilobum only. All mulches increased soil moisture compared with no mulch + weed control. There was no difference in soil pH or foliar nitrogen among treatments. All mulches, except cypress mulch, increased plant growth of most shrub taxa compared with no mulch without weed control. Mulches increased $g_{S}$ relative to no mulch without weed control. Photosynthetic rates of plants mulched with cypress mulch were less than the other mulches and not different from no mulch. Overall, the result suggests that, except for cypress mulch, the organic mulches tested are equally effective in improving growth of landscape plants. Reduced photosynthetic efficiency and growth of shrubs with cypress mulch suggest potential allelopathic effects.

Landscape mulches are an important component to improving the sustainability of landscape systems. Mulches, particularly organic mulches, can enhance sustainability by reducing chemical inputs and the use of fossil fuels to maintain healthy and aesthetically pleasing landscapes. The effects of mulches on environmental factors and landscape plant growth have been widely studied [see Chalker-Scott (2007) for a comprehensive review]. Mulches provide an array of landscape benefits, including improving soil moisture (Fraedrich and Ham, 1982; Iles and Dosmann, 1999; Kraus, 1998; Litzow and Pellett 1993; Watson, 1988; Watson and Kupkowski, 1991), maintaining

\footnotetext{
Received for publication 11 Mar. 2009. Accepted for publication 17 Apr. 2009.

We thank Dr. Dan Brainard, Dr. Brad Rowe, and three anonymous reviewers for their helpful reviews of this manuscript. We gratefully acknowledge Dr. Gerry Adams for initial planning and development of the project and Dan Little for assessing weed populations. We thank Anna Arend, Darren Gladstone, Jennifer Hunnell, Sara Tanis, and Wendy Klooster for assisting with field data collection.

${ }^{1}$ Associate Professor.

${ }^{2}$ To whom reprint requests should be addressed; e-mail cregg@msu.edu.
}

optimum soil temperatures (Fraedrich and Ham, 1982; Montague and Kjelgren, 2004), moderating energy budgets and reflected heat load (Montague et al., 2007), improving soil nutrition (Greenly and Rakow, 1995), and improving landscape plant growth (Green and Watson, 1989; Greenly and Rakow, 1995; Lithow and Pellett, 1993).

Although the overall benefits of mulches have been well established, a question we frequently field in our extension and outreach work with landscape professionals and homeowners is, "Which mulch should I use?" Distilling down the information on mulches can be difficult because many studies consider only one or two response factors or deal with mulches that may not be commonly available.

Table 1. Description of weed control and mulch treatments in Michigan State University Landscape Mulch Trial.

\begin{tabular}{ll}
\hline Treatment & \multicolumn{1}{c}{ Description } \\
\hline No mulch + no weed control & No mulch, no weed control \\
No mulch + weed control & No mulch, weeds controlled by hand-weeding \\
& and directed application of glyphosate \\
Cypress (maximum particle size $25 \mathrm{~mm}$ ) & Mulched with $8 \mathrm{~cm}$ of ground cypress \\
Recycled pallets (maximum particle & Mulched with $8 \mathrm{~cm}$ of ground pallets, \\
size $20 \mathrm{~mm}$ ) & color-enhanced red \\
Hardwood fines (maximum particle size $10 \mathrm{~mm}$ ) & Mulched with $8 \mathrm{~cm}$ of ground hardwood fines \\
Pine bark (maximum particle size $20 \mathrm{~mm}$ ) & Mulched with $8 \mathrm{~cm}$ of ground red pine bark \\
\hline
\end{tabular}

To gain greater insights into the effectiveness of mulches for midwestern landscapes, we established a landscape mulch study at the Michigan State University Horticulture Teaching and Research center in late Summer 2004. The goal of the project was to determine the response of several common landscape shrubs to four widely used and commercially available mulches (pine bark, cypress mulch, hardwood mulch, and colorenhanced ground recycled pallets) over 3 years. We chose to focus on organic mulches because their superiority over inorganic mulches has been well documented in the literature (Chalker-Scott, 2007). In addition to the mulches, we included two treatments without mulch, no mulch + no weed control and no mulch + weed control, to separate the effect of weed control from the overall mulch effect.

Specific objectives of the project were to determine the effect of mulch and weed control on shrub growth, photosynthetic gas exchange, foliar nutrition, soil moisture, soil $\mathrm{pH}$, and populations of common weeds.

\section{Materials and Methods}

Site and treatments. The study was installed in Aug. 2004 at the Michigan State University Teaching and Research Center near East Lansing, MI. The study area is flat and the soils are a Capac loam (fine-loamy, mixed, active, mesic Aquic Glossudalfs). The area had not been in crop production for the past 3 years and the existing vegetation was primarily perennial grasses that were mowed periodically. We prepared $243.7 \mathrm{~m} \times 3.7-\mathrm{m}$ $(12-\mathrm{ft} \times 12-\mathrm{ft})$ plots by trenching around each plot to a depth of $0.9 \mathrm{~m}(3 \mathrm{ft})$ and lining the perimeter of the plots with heavy $(6-\mathrm{mm}$ thick) black plastic. Vegetation in the plots was sprayed with glyphosate and then rototilled $\approx 1$ month before installation of the experiment. We planted 10 shrubs from eight taxa in each plot. Taxa used were burning bush (Euonymus alatus 'Compactus'), 'Goldflame' spirea (Spiraea ×bumalda 'Goldflame'), 'Java red' weigela (Weigela florida 'Java red'), 'Runyan' yew (Taxus ×media 'Runyan'), 'Golden globe' arborvitae (Thuja occidentalis 'Golden Globe'), Tardiva hydrangea (Hydrangea paniculata 'Tardiva'), Chicago Lustre ${ }^{\circledR}$ arrowwood viburnum ( $\mathrm{Vi}$ burnum dentatum 'Synnestvedt'), and cranberrybush viburnum (Viburnum trilobum 'Compactum'). One shrub of each taxa was planted in each plot except for 'Golden 
Globe' arborvitae and 'Runyan' yew, which were represented by two plants per plot as a result of greater availability. All plants were donated from a local wholesale nursery and grown in No. 3 (10.5-L) containers. Some plants exhibited circling roots, which were teased apart and separated by hand before planting. Root systems were not sliced or "butterflied." After planting, we mulched plots to an uncompacted depth of $8 \mathrm{~cm}$ with one of four organic mulches: ground red pine bark, ground recycled pallets, hardwood bark fines, or ground cypress mulch (Table 1). Two additional plots in each replication were not mulched; one plot served as an unmulched control and the other was maintained weedfree by hand-weeding and directed sprays of glyphosate. The study was installed as a split plot in a randomized complete block with four blocks. Mulch was applied as the main plot factor and shrub taxa was considered the subplot factor. Blocks were arranged to account for potential variation in soil across the field. All plots were irrigated weekly in August and early Sept. 2004 to aid in initial plant establishment. Survival of all plants at the initiation of measurements in Spring 2005 was $100 \%$. No fertilization was added during the study and no additional mulch was added after plot installation, i.e., plots were not "top-dressed."

Measurements. We measured plant height $(h)$ and crown width in two directions ( $w_{l}$ and $w_{2}$ ) on each shrub at the beginning and end of the 2005, 2006, and 2007 growing seasons. Crown volume index $(V)$ was calculated as $V=h \times w_{1} \times w_{2}$. Rainfall and reference evapotranspiation $\left(\mathrm{ET}_{\mathrm{o}}\right.$ ) for the site was compiled from the Michigan Automated Weather Network weather station located $\approx 600 \mathrm{~m}$ from the study. Reference evapotranspiration was estimated by the FAO Penment-Montheith calculation (Allen et al., 1998).

We measured soil moisture every 7 to $14 \mathrm{~d}$ on each plot through the 2005 and 2006 growing seasons using a portable TDR system (TRASE; Soil Moisture Equipment, Inc., Santa Barbara, CA). Soil moisture was measured at 0 to $15 \mathrm{~cm}$ and 0 to $45 \mathrm{~cm}$ below the soil surface near the center of each plot.

Photosynthetic gas exchange and stomatal conductance $\left(g_{\mathrm{S}}\right)$ to water vapor were measured on Hydrangea paniculata, Viburnum dentatum, and Viburnum trilobum plants on two dates in 2006 and two dates in 2007 using a portable photosynthesis system (LI-6400; LI-COR, Inc., Lincoln, NE). Hydrangea and the two Viburnum species were selected for gas exchange measurements because they have relatively large leaves that completely covered the $2 \times 3-\mathrm{cm}$ leaf chamber of the portable photosynthesis system. This approach simplified gas exchange measurements and eliminated the need to correct gas exchange measurements resulting from partial coverage of the leaf chamber. All gas exchange measurements were completed near midday (1000 to $1600 \mathrm{HR}$ ) on clear days. To reduce environmental noise in the gas exchange data, the light control system on the LI-6400 was set to $1500 \mu \mathrm{mol} \cdot \mathrm{m}^{-2} \cdot \mathrm{s}^{-1}$, the

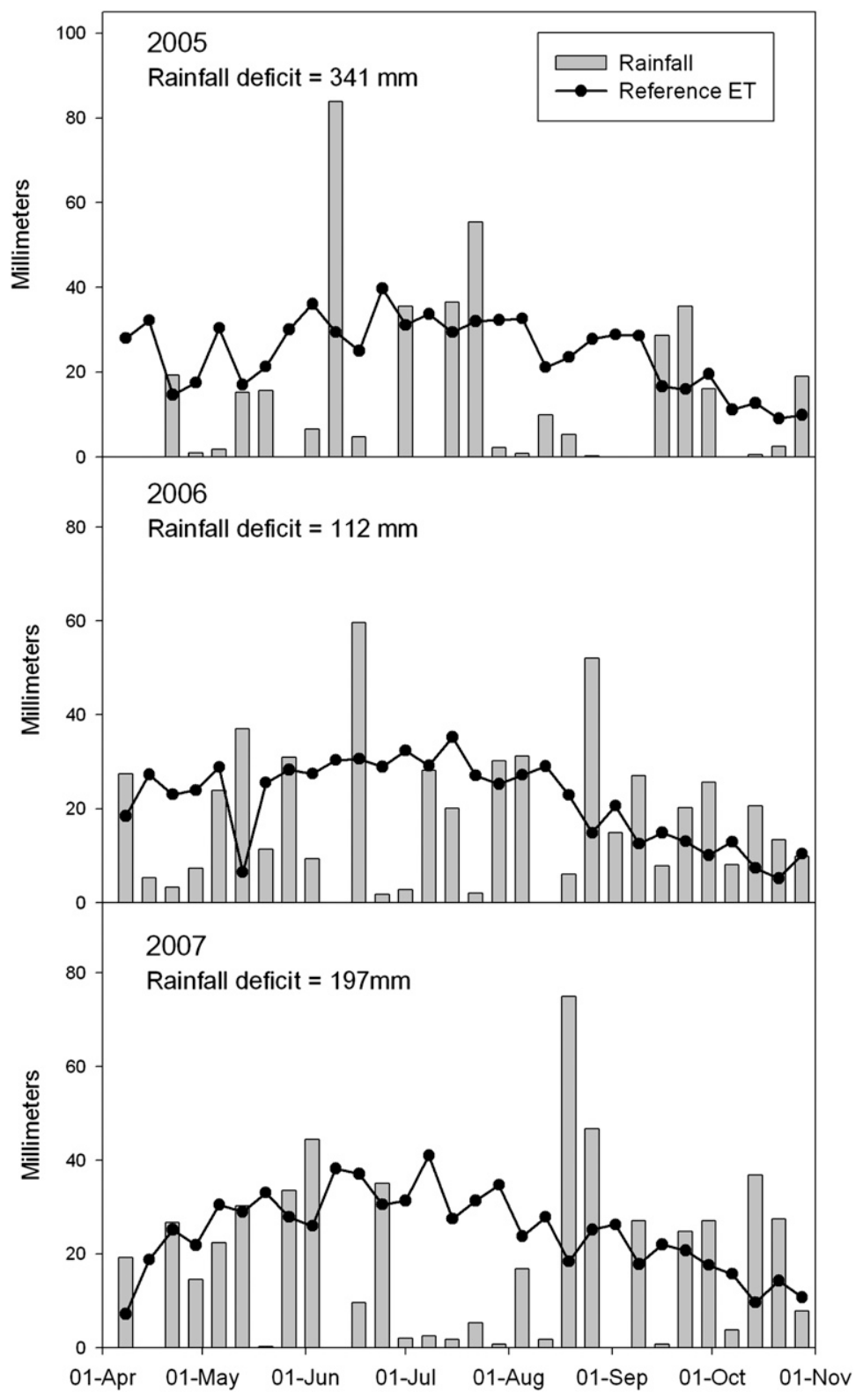

Fig. 1. Weekly rainfall and reference evapotranspiration (ET) from Michigan Automated Weather Network Site at Michigan State University Horticulture Teaching and Research Center, East Lansing, MI, 2005 to 2007. Rainfall deficit = reference ET - rainfall.

Table 2. Mean ( $\pm \mathrm{SE}$ ) volumetric soil moisture at 0 - to $15-\mathrm{cm}$ and 0 - to $45-\mathrm{cm}$ depth under mulches and without mulch, Michigan State University Mulch Study, 2005-2006.

\begin{tabular}{|c|c|c|c|c|}
\hline \multirow{2}{*}{$\begin{array}{l}\text { Depth: } 0 \text { to } 15 \mathrm{~cm} \\
\text { Treatment }\end{array}$} & \multicolumn{4}{|c|}{ Volumetric soil moisture (\%) } \\
\hline & \multicolumn{2}{|c|}{2005} & \multicolumn{2}{|c|}{2006} \\
\hline No mulch + no weed control & $18.74 \mathrm{z} \mathrm{a}$ & $(1.11)$ & $22.96 \mathrm{ab}$ & $(1.52)$ \\
\hline No mulch + weed control & $16.81 \mathrm{a}$ & (1.11) & $18.65 \mathrm{a}$ & $(1.56)$ \\
\hline Cypress mulch & $26.90 \mathrm{~b}$ & (1.15) & $24.59 \mathrm{ab}$ & $(1.47)$ \\
\hline Recycled pallets & $24.72 \mathrm{~b}$ & (1.11) & $21.38 \mathrm{ab}$ & $(1.49)$ \\
\hline Hardwood fines & $26.73 \mathrm{~b}$ & (1.12) & $25.70 \mathrm{~b}$ & $(1.47)$ \\
\hline Pine bark & $25.70 \mathrm{~b}$ & (1.11) & $25.74 \mathrm{~b}$ & $(1.44)$ \\
\hline Depth: 0 to $45 \mathrm{~cm}$ & \multicolumn{4}{|c|}{ Volumetric soil moisture (\%) } \\
\hline Treatment & \multicolumn{2}{|c|}{2005} & \multicolumn{2}{|c|}{2006} \\
\hline No mulch + no weed control & $22.27 \mathrm{~b}$ & $(1.05)$ & $26.65 \mathrm{~b}$ & $\overline{(0.94)}$ \\
\hline No mulch + weed control & $16.15 \mathrm{a}$ & (1.04) & $17.00 \mathrm{a}$ & $(0.95)$ \\
\hline Cypress mulch & $25.82 \mathrm{~b}$ & $(1.05)$ & $26.86 \mathrm{~b}$ & $(0.91)$ \\
\hline Recycled pallets & $24.64 \mathrm{~b}$ & $(1.03)$ & $24.71 \mathrm{~b}$ & $(0.92)$ \\
\hline Hardwood fines & $26.47 \mathrm{~b}$ & $(1.03)$ & $26.86 \mathrm{~b}$ & $(0.91)$ \\
\hline Pine bark & $23.61 \mathrm{~b}$ & (1.04) & $25.26 \mathrm{~b}$ & $(0.88)$ \\
\hline
\end{tabular}

${ }^{\mathrm{z}}$ Means followed by the same letter are not different at the $P<0.05$ level. Mean separation by Tukey's Studentized range test. 
temperature control block was set to the predicted high temperature for each measurement day, and the $\mathrm{CO}_{2}$ mixer was set to 400 ppm $\mathrm{CO}_{2}$. Three gas exchange measurement were collected on fully expanded leaves at the mid- to upper crown of each shrub. Measurements were logged when the real-time graphics display on the instrument indicated gas exchange was stable and the $\mathrm{CV}$ of the rolling average of photosynthesis calculated by the LI-6400 was less than $2 \%$. Intrinsic water use efficiency (WUEi) was calculated from gas exchange measurements as: $W U E i=$ $A / g_{w v}$, where: $A=$ net photosynthetic rate in $\mu \mathrm{mol} \mathrm{CO} 2 / \mathrm{m}^{-2} \cdot \mathrm{s}^{-1}$ and $g_{w v}$ is leaf conductance to water vapor in $\mathrm{mmol} \mathrm{H}_{2} \mathrm{O} / \mathrm{m}^{-2} \cdot \mathrm{s}^{-1}$.

In Aug. 2006, foliar nitrogen was determined for Hydrangea paniculata, Viburnum dentatum, and Viburnum trilobum. Approximately $20 \mathrm{~g}$ (fresh weight) of fully expanded leaves were collected from each plant. Leaves were oven-dried, ground, and analyzed at a commercial laboratory (Waters Agricultural Laboratory, Camilla, GA).

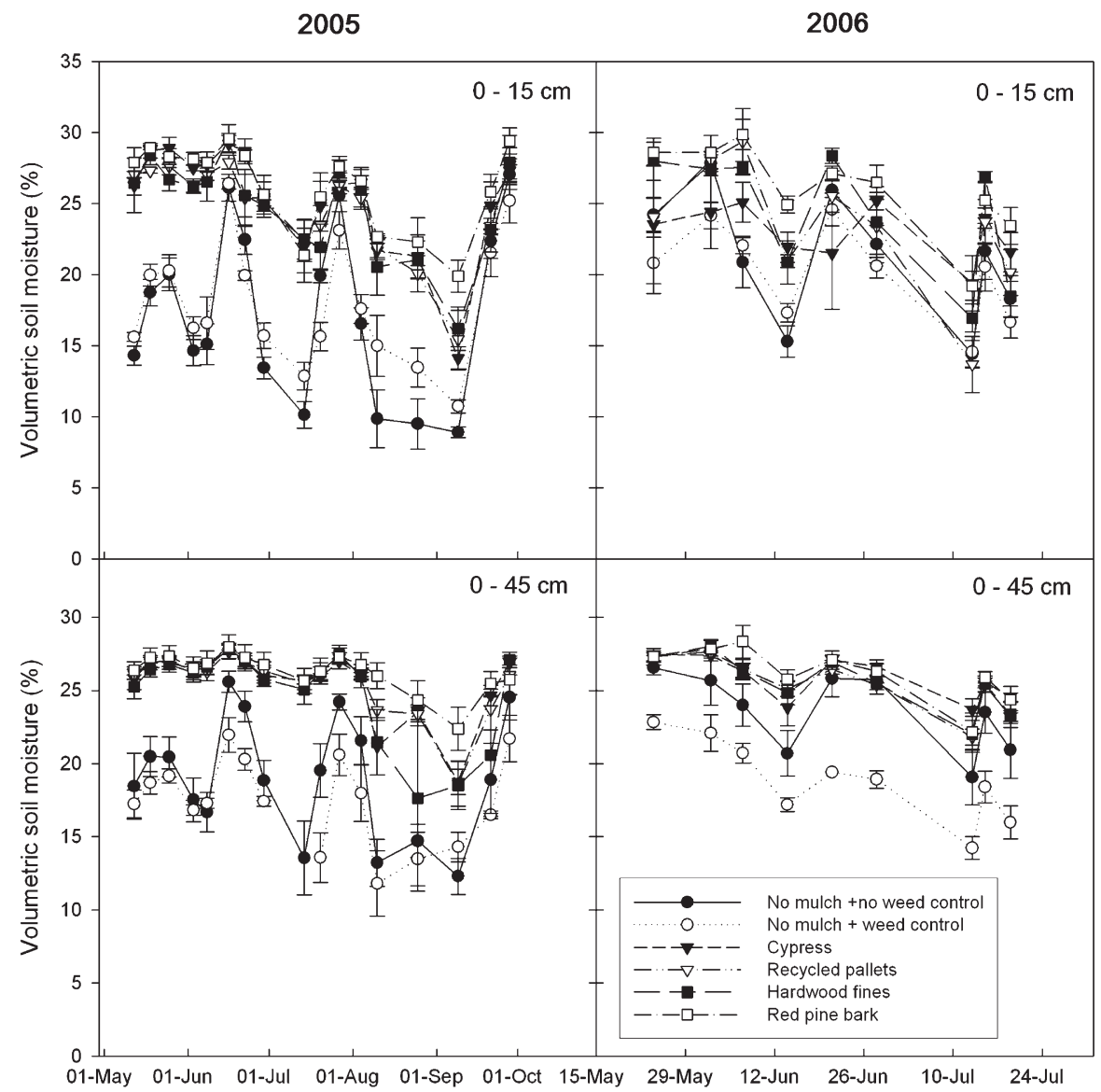

Fig. 2. Mean ( $\pm \mathrm{SE}$ ) volumetric soil moisture at 0 to $15 \mathrm{~cm}$ and 0 to $45 \mathrm{~cm}$ for landscape plots with $8 \mathrm{~cm}$ organic mulches or unmulched with and without weed control, Michigan State University Horticulture Teaching and Research, East Lansing, MI, 2005 to 2006. N = 4 for all means.

Soil $\mathrm{pH}$ was determined for each plot in Aug. 2006. Twelve soil samples were collected at a depth of 0 to $15 \mathrm{~cm}$ below the soil surface in each plot using a $17-\mathrm{mm}$ diameter push-type soil probe and composited in a clean bucket. Soil samples were well mixed and a subsample was used for $\mathrm{pH}$ measurements. Soil $\mathrm{pH}$ was determined on each sample using a 1:1 (v:v) mix of soil and deionized water with a $\mathrm{pH}$ meter (Model AB15; Fisher Scientific, Pittsburgh, PA).

Weed competition was assessed near at the end of the 2006 growing season. A complete census of all weeds was conducted in each plot. Nine weeds were identified to species. Annual grasses were composited in one category. Additional weeds were counted as "other."

Analysis. Overall growth and survival data were analyzed by analysis of variance based on a split plot in a randomized complete block with mulch or weed control as the main plot and taxa as the subplot using the model $y_{i j k}=\mu+\alpha_{i}+\beta_{j}+\alpha \beta_{i j}+\gamma_{k}+\alpha \gamma_{i k}+$ $\varepsilon_{i j k}$ where: $\mu=$ the overall mean, $\alpha_{i}=$ mulch/ weed control, $\beta_{\mathrm{j}}=$ block effect, $\alpha \beta_{\mathrm{ij}}=$ main plot error term (Error A), $\gamma_{\mathrm{k}}=$ taxa effect, $\alpha \gamma_{\mathrm{ik}}=$ mulch/weed control $\times$ taxa interaction, $\varepsilon_{\mathrm{ijk}}=$ subplot error (Error B).

Where significant $(P<0.05)$ mulch effects were indicated, weed population means were separated by Fisher's least significant difference test. All other means were separated by Tukey's Studentized range test.

\section{Results}

Weather. Weather patterns varied among the 3 years of the study (Fig. 1). Year 2005 was the driest year during the study. Over the 2005 growing season, reference potential evapotranspiration exceeded rainfall by 341 $\mathrm{mm}$. Reference ET exceeded rainfall in 18 of 23 weeks between 1 Apr. and 15 Sept. 2005. A late-season dry spell was noteworthy because only $19 \mathrm{~mm}$ of rain fell during a 7 week span from late July to mid-September. Rainfall was more consistent in 2006 than in 2005 and the rainfall deficit $(-112 \mathrm{~mm})$ was the smallest of the 3 study years. Year 2007 was intermediate between 2005 and 2006 in

Table 3. Mean weed counts in plots with organic mulches or unmulched with and without weed control, Michigan State University Horticulture Teaching and Research, East Lansing, MI, Sept. 2006.

\begin{tabular}{|c|c|c|c|c|c|c|}
\hline \multirow[b]{2}{*}{ Weed } & \multicolumn{6}{|c|}{ Weed count $/ \mathrm{m}^{2}$} \\
\hline & $\begin{array}{l}\text { No mulch + no } \\
\text { weed control }\end{array}$ & $\begin{array}{l}\text { No mulch }+ \\
\text { weed control }\end{array}$ & Cypress & Pallet & Hard-wood & Pine-bark \\
\hline \multicolumn{7}{|l|}{ Common dandelion (Taraxacum officinale } \\
\hline Annual grasses & $15.9 \mathrm{a}$ & $0.0 \mathrm{~b}$ & $1.3 \mathrm{~b}$ & $1.7 \mathrm{~b}$ & $5.8 \mathrm{~b}$ & $0.7 \mathrm{~b}$ \\
\hline Annual sowthistle (Sonchus oleraceus L.) & $0.8 \mathrm{c}$ & $0.0 \mathrm{c}$ & $4.6 \mathrm{ab}$ & $5.6 \mathrm{a}$ & $7.5 \mathrm{a}$ & $1.6 \mathrm{bc}$ \\
\hline Redroot pigweed (Amaranthus retroflexus L.) & $1.6 \mathrm{a}$ & $0.0 \mathrm{~b}$ & $0.6 \mathrm{~b}$ & $0.2 \mathrm{~b}$ & $0.1 \mathrm{~b}$ & $0.4 \mathrm{~b}$ \\
\hline Yellow nutsedge (Cyperus esculentus L.) & $0.0 \mathrm{a}$ & $0.0 \mathrm{a}$ & $0.8 \mathrm{a}$ & $0.0 \mathrm{a}$ & $0.2 \mathrm{a}$ & $2.0 \mathrm{a}$ \\
\hline Wild carrot (Daucus carota L.) & $1.3 \mathrm{a}$ & $0.0 \mathrm{a}$ & $0.1 \mathrm{a}$ & $0.1 \mathrm{a}$ & $0.2 \mathrm{a}$ & $0.0 \mathrm{a}$ \\
\hline Horseweed [Conyza canadensis (L.) Cronq.] & $1.0 \mathrm{a}$ & $0.0 \mathrm{~b}$ & $0.0 \mathrm{~b}$ & $0.0 \mathrm{~b}$ & $0.1 \mathrm{~b}$ & $0.0 \mathrm{~b}$ \\
\hline Buckhorn plantain (Plantago lanceolata L.) & $0.0 \mathrm{a}$ & $0.0 \mathrm{a}$ & $0.8 \mathrm{a}$ & $0.0 \mathrm{a}$ & $0.0 \mathrm{a}$ & $0.1 \mathrm{a}$ \\
\hline Others & $1.8 \mathrm{a}$ & $0.0 \mathrm{a}$ & $0.2 \mathrm{a}$ & $0.3 \mathrm{a}$ & $0.6 \mathrm{a}$ & $1.1 \mathrm{a}$ \\
\hline
\end{tabular}

${ }^{2}$ Means within a row followed by the same letter are not different at the $P<0.05$ level. Mean separation according to Fisher's protected least significant difference test. 
terms of total rainfall and rainfall deficit. A 7week dry period occurred from early July until mid-Aug. 2007 during which only 31 $\mathrm{mm}$ of rain fell.

Soil moisture. Mulching increased $(P<$ 0.05 ) soil moisture compared with no mulch + weed control at 0 to $15 \mathrm{~cm}$ and 0 to $45 \mathrm{~cm}$ in 2005 and 2006 (Table 2). There was no difference in soil moisture among mulches in either year at either depth. At 0- to $15-\mathrm{cm}$ depth, soil moisture was slightly, but not significantly, lower in no mulch + weed control than without weed control. At 0 to $45 \mathrm{~cm}$, soil moisture in the no weed control plot was greater than no mulch + weed control. Also, soil moisture increased without weed control in 2006 compared with 2005.

Seasonal patterns of soil moisture without mulch + weed control and without weed control closely followed rainfall in 2005 (Fig. 2). Soil moisture peaked after heavy rainfall in late June and late July and then declined. Soil moisture reached the lowest levels during the dry-down period in August and early Sept. 2005. In 2006, rainfall was more consistent than in 2005 and soil moisture was generally higher and treatment effects were less pronounced at the 0 - to 15 $\mathrm{cm}$ depth. For the entire study, there were no differences in soil moisture among any of the mulches on any of the 27 measurements dates at either 0 - to $15-\mathrm{cm}$ or 0 - to $45-\mathrm{cm}$ soil depth.

Soil $p H$. Soil $\mathrm{pH}$ did not vary $(P>0.05)$ among the treatments (data not shown). Mean $\mathrm{pH}$ of all treatments ranged from neutral to slightly acidic.

Weed control. Mulches were effective in reducing many of the most common weeds in the study area (Table 3). Populations of common dandelion, annual grasses, redroot pigweed, and horseweed were lower $(P<$ $0.05)$ on mulched plots than plots with no weed control. Populations of annual sowthistle, however, were greater $(P<0.05)$ on plots mulched with cypress, ground pallets, or hardwood fines than the no weed control plots. This suggests that the mulch itself may have provided an adequate seedbed for germination and development of sowthistle or that the mulch depth was insufficient to provide adequate control (Abouziena et al., 2008).

Growth. Treatment, taxa, and the interaction of treatment $\times$ taxa affected $(P<0.01)$ crown height, crown diameter, and crown volume of shrubs after 3 years (Table 4). Patterns of variation were similar among growth variables; therefore, only height growth is presented in detail to simplify data presentation (Fig. 3). Plants mulched with pine bark, hardwood fines, or ground pallets grew more than plants in the unmulched plots without weed control for five of eight taxa. For all taxa, there was no difference in growth of plants mulched with pine bark, hard wood fines, or ground pallets. Weed control alone increased plant growth compared with plants in the no weed control plots, although the difference was significant only for $V$. trilobum. Averaged across all taxa, plants mulched with cypress mulch grew less $(P<0.01)$ than plants mulched with the other organic materials (data not shown). Growth of shrubs mulched with cypress mulch did not differ $(P>0.25)$ from

growth of plants in the no mulch + weed control plots for any of the taxa.

Viburnum trilobum plants grew more than plants from the other taxa, averaging $0.87 \mathrm{~m}$ in height growth, followed by Hydrangea

Table 4. Summary analysis of variance (F-values) for 3-year growth response of landscape shrubs grown with organic mulches or unmulched with and without weed control, Michigan State University Horticulture Teaching and Research, East Lansing, MI.

\begin{tabular}{lrcrr}
\hline Source & df & Crown ht & Crown diam & $\begin{array}{c}\text { Crown volume } \\
\text { index }^{\mathrm{z}}\end{array}$ \\
\hline Block & 3 & $1.80^{\mathrm{y}}$ & 0.25 & 1.59 \\
Mulch & 5 & $16.16^{* * *}$ & $20.11^{* * *}$ & $28.54 * * *$ \\
Error A & 15 & & & $149.54 * * *$ \\
Species & 7 & $109.92^{* * *}$ & $123.93^{* * *}$ & $7.18^{* * *}$ \\
Species $\times$ mulch & 35 & $1.87^{* *}$ & $3.53^{* * *}$ & \\
Error B & 174 & & & \\
\hline
\end{tabular}

${ }^{\mathrm{z}}$ Volume $=$ diameter $^{2} \times$ height.

${ }^{\mathrm{y}} \mathrm{F}$-value significance indicated as: ${ }^{*} P<0.05 ; * * P<0.01 ; * * * P<0.001$.

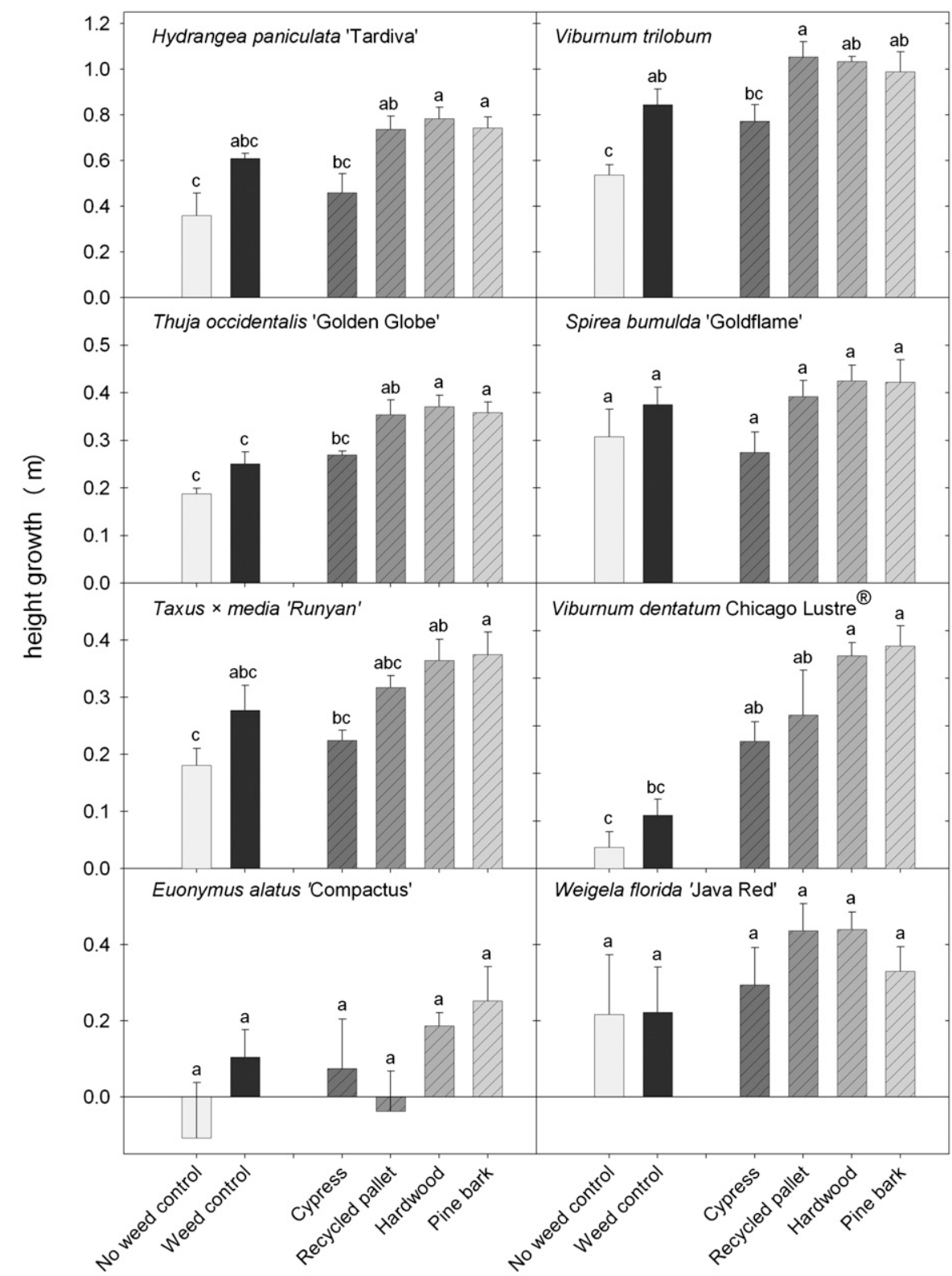

Fig. 3. Mean ( $\pm \mathrm{SE}$ ) cumulative 3-year height growth of landscape shrubs mulched with four types of organic mulch or unmulched with and without weed control. Means within a species denoted by the same letter are not different at the $P=0.05$ level based on Tukey's Studentized range test. 
paniculata at $0.62 \mathrm{~m}$. Euonymus plants grew slowly and several plants suffered dieback, particularly with no mulch/no weed control or mulched with recycled pallets.

Foliar nitrogen. Treatment and taxa affected $(P<0.05)$ foliar nitrogen $(\mathrm{N})$ concentration, but the interaction effect of taxa $\times$ treatment was not significant. Plants mulched with hardwood fines had greater foliar $\mathrm{N}$ concentration than plants with no weed control or plants mulched with cypress mulch (Table 5). There was no difference in foliar $\mathrm{N}$ among the other mulch treatments. Among the taxa, Hydrangea plants had greater $(P<$ 0.05 ) foliar $\mathrm{N}$ than Viburnum plants.

Photosynthetic gas exchange. All mulches, except cypress mulch, increased $(P<0.05)$ net photosynthesis compared with no weed control (Table 6) and similar patterns were observed within specific taxa investigated (Fig. 4). Net photosynthesis of plants without mulch + weed control or cypress mulch was intermediate between no weed control and the other mulches. Mulches generally increased $g_{\mathrm{S}}$ to water vapor, reflecting the improvement of soil moisture availability with all of the mulches. Lower photosynthesis of plants with cypress mulch relative to the other mulches appears to be related to nonstomatal or biochemical changes in the photosynthetic system. $G_{\mathrm{S}}\left(g_{w v}\right)$ was affected by the presence of mulch, but there was no difference in $g_{w v}$ among mulches (Table 6). Intrinsic water use efficiency (ratio of $A / g_{w v}$ ) decreased significantly for plants mulched with cypress compared with no mulch + weed control.

Table 5. Mean foliar nitrogen (N) concentration of Hydrangea paniculata 'Tardiva', Viburnum dentatum 'Synnestvedt', and Viburnum trilobum 'Bailey Compact' grown for 2 years with organic mulches or unmulched with and without weed control, Michigan State University Horticulture Teaching and Research, East Lansing, MI.

\begin{tabular}{lcccc}
\hline & \multicolumn{4}{c}{ Foliar N (\%) } \\
\cline { 2 - 5 } Treatment & Hydrangea & V. dentatum & V. trilobum & Overall \\
\hline No mulch + no weed control & 1.83 & 1.34 & 1.58 & $1.58 \mathrm{~b}$ \\
No mulch + weed control & 1.84 & 1.49 & 1.53 & $1.62 \mathrm{ab}$ \\
Cypress mulch & 1.92 & 1.40 & 1.36 & $1.56 \mathrm{~b}$ \\
Recycled pallets & 1.97 & 1.81 & 1.29 & $1.69 \mathrm{ab}$ \\
Hardwood fines & 2.14 & 1.79 & 1.82 & $1.92 \mathrm{a}$ \\
Pine bark & 1.97 & 1.89 & 1.64 & $1.83 \mathrm{ab}$ \\
Overall & $1.94^{\mathrm{z}} \mathrm{A}$ & $1.62 \mathrm{~B}$ & $1.54 \mathrm{~B}$ & \\
\hline
\end{tabular}

${ }^{\mathrm{z}}$ Means within a row followed by the same upper case letter and means within a column followed the same lower case letter are not different at the $P<0.05$ level. Mean separation by Tukey's Studentized range test. Within-taxa mean foliar $\mathrm{N}$ concentrations did not differ $(P>0.05)$ among treatments.

Table 6. Mean net photosynthesis, stomatal conductance $\left(g_{\mathrm{S}}\right)$ to water vapor, and intrinsic water use efficiency of landscape shrubs growth with organic mulches or unmulched with and without weed control, Michigan State University Horticulture Teaching and Research, East Lansing, MI, 2006 to 2007.

\begin{tabular}{lccc}
\hline Treatment & $\begin{array}{c}\text { NET photosynthesis } \\
\left(\mu \mathrm{mol} \cdot \mathrm{m}^{-2} \cdot \mathrm{s}^{-1}\right)\end{array}$ & $\begin{array}{c}\text { Intrinsic water use } \\
\text { efficiency }\end{array}\left(\mu \mathrm{mol}^{\mathrm{z}} \cdot \mathrm{mmol}^{-1}\right)$ \\
\hline No mulch + no weed control & $7.63^{\mathrm{y}} \mathrm{b}$ & $0.15 \mathrm{c}$ & $54.5 \mathrm{ab}$ \\
No mulch + weed control & $9.32 \mathrm{ab}$ & $0.17 \mathrm{bc}$ & $60.6 \mathrm{a}$ \\
Cypress & $9.31 \mathrm{ab}$ & $0.22 \mathrm{a}$ & $47.6 \mathrm{~b}$ \\
Hardwood & $10.23 \mathrm{a}$ & $0.21 \mathrm{ab}$ & $56.7 \mathrm{ab}$ \\
Pallet & $10.79 \mathrm{a}$ & $0.23 \mathrm{a}$ & $51.8 \mathrm{ab}$ \\
Pine bark & $10.60 \mathrm{a}$ & $0.21 \mathrm{ab}$ & $54.6 \mathrm{ab}$ \\
\hline
\end{tabular}

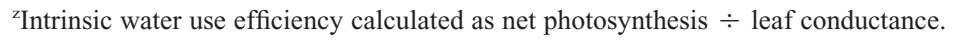

${ }^{y}$ Means within a column followed by the same letter are not different at $P<0.05$. Mean separation by

Tukey's Studentized range test. contributed to greater overall transpiration and soil moisture depletion, particular at the 0 - to $45-\mathrm{cm}$ soil depth, than shrubs without weed control.

Lack of mulch effects on soil $p H$ and foliar plant nutrition. Chalker-Scott (2007) noted that two assumptions regarding organic mulches; acidification of soil and nutrient "tie-up" are rarely supported by the literature. In the present study, there was no difference in soil $\mathrm{pH}$ among any of the mulches or between mulched and unmulched plots. Similarly, Greenly and Rakow (1995) observed no difference in soil $\mathrm{pH}$ of soils mulched for 2 years with $0,7.5,15$, or $25 \mathrm{~cm}$ of shredded hardwood chips or chipped pine bark. Iles and Dosmann (1999) found that pine mulch and hardwood mulch increased soil $\mathrm{pH}$ compared with bare ground. In the present study, we found no evidence of nutrient depletion or reduced foliar $\mathrm{N}$ of plants grown with mulch compared with bare ground (no mulch + weed control). Within the mulch treatments, plants grown with hardwood mulch had greater foliar $\mathrm{N}$ than plants grown with cypress mulch. The hardwood material was ground finer than the other mulches, which may lead to more rapid decomposition, especially relative to cypress, which contains a large amount of extractives (Panshin and deZeeuw, 1980). Our results are consistent with several mulch studies in the arboricultural literature, which suggest that organic mulches have no effect, or may improve, nutrient availability (Fraedrich and Ham, 1982; Greenly and Rakow, 1995).

Reduction in growth and photosynthetic efficiency of plants mulched with cypress mulch compared with other mulches. Among the mulches we observed, a general trend that landscape shrubs grew less with cypress mulch than with the other mulches, particularly pine bark or hardwood mulch. Circumstantial evidence suggests that the effect of cypress mulch may, at least in part, be allelopathic. Allelopathic effects of mulch are generally viewed in terms of suppression of seed germination, especially weed seeds. For example, Duryea et al. (1999) observed allelopathic effects of several fresh mulches in bioassays on germination of lettuce seeds. Salicylic acid from bark of Chamaecyparis obtusa induced allelopathic effects on seeds of plants native to the species' range in Taiwan as well as on seeds of exotic plants (Tseng et al., 2007). Allelopathic effects on newly planted or existing woody landscape plants, however, have not been documented.

Conclusively demonstrating allelopathic effects can often be extraordinarily difficult (Halsey, 2004), but several lines of evidence suggest it may occur with cypress mulch. As noted previously, soil $\mathrm{pH}$ and foliar nutrient levels were similar among mulches tested, indicating neither factor can explain reduced growth of plants with cypress mulch. Soil moisture and plant moisture stress (as evidenced by $g_{\mathrm{S}}$ to water vapor) were nearly identical among mulches, indicating all mulches tested were equally effective in reducing plant stress. However, net photosynthetic rate of 


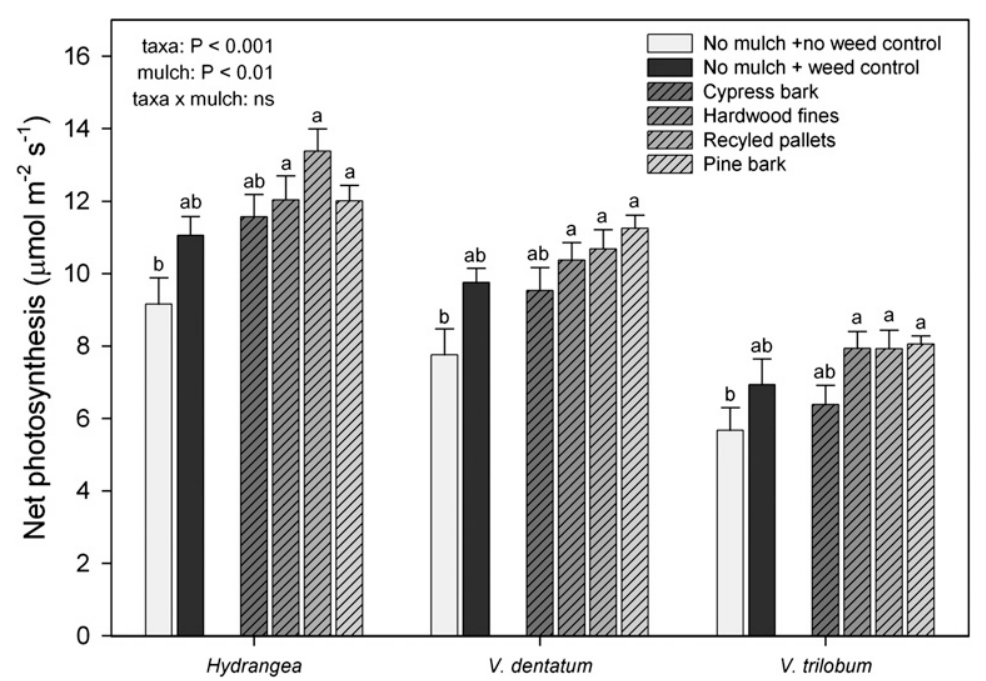

Fig. 4. Mean ( $\pm \mathrm{SE})$ net photosynthesis of Hydrangea paniculata 'Tardiva', Viburnum dentatum 'Synnestvedt', and Viburnum trilobum 'Compactum' grown with organic mulches or unmulched with and without weed control, Michigan State University Horticulture Teaching and Research, East Lansing, MI. Means averaged from four dates in 2006 to 2007. Means within a species denoted by the same letter are not different at the $P=0.05$ level based on Tukey's Studentized range test.

plants grown with cypress mulch was the lowest among mulches tested and WUE (the ratio of net photosynthesis to $g_{S}$ ) of plants with cypress mulch was lowest among all treatments applied. It should be noted that the plants studied were newly planted at the start of the study. It is uncertain whether mulching well-established plants with cypress would have similar impacts. Clearly, additional factors may be responsible for the reduced shrub growth observed with cypress mulch, but the potential role of allelopathy warrants further investigation.

\section{Literature Cited}

Abouziena, H.F., O.M. Hafez, I.M. El-Metwally, S.D. Sharma, and M. Singh. 2008. Comparison of weed suppression and mandarin fruit yield and quality obtained with organic mulches, synthetic mulches, cultivation, and glyphosate. HortScience 43:795-799.

Allen, R.G., L.S. Pereira, D. Raes, and M. Smith. 1998. Crop evapotranspiration-Guidelines for computing crop water requirements. FAO Irrigation and Drainage Paper 56. Food and Agriculture Organization of the United Nations, Rome, Italy.

Chalker-Scott, L. 2007. Impact of mulches on landscape plants and the environment-A review. J. Environ. Hort. 25:239-249.

Duryea, M.L., R.J. English, and L.A. Hermansen. 1999. A comparison of landscape mulches: Chemical, allelopathic, and decomposition properties. J. Arbor. 25:88-97.

Fraedrich, S.W. and D.L. Ham. 1982. Wood chip mulching around maples: Effect on tree growth and soil characteristics. J. Arbor. $8: 85-89$.

Green, T.L. and G.W. Watson. 1989. Effects of turfgrass and mulch on establishment and growth of bareroot sugar maples. J. Arbor. 15:268-272.

Greenly, K. and D. Rakow. 1995. The effects of mulch type and depth of weed and tree growth. J. Arbor. 21:225-232.

Halsey, R.W. 2004. In search of allelopathy: An eco-historical view of the investigation of chemical inhibition in California coastal sage scrub and chamise. J. Torrey Bot. Soc. 131:343-367.

Iles, J.K. and M.S. Dosmann. 1999. Effect of organic and mineral mulches on soil properties and growth of 'Fairview Flame R' red maples trees. J. Arbor. 25:163-167.

Kraus, H.T. 1998. Effects of mulch on soil moisture and growth of desert willow. HortTechnology 8:588-590.

Litzow, M. and H. Pellett. 1993. Influence of mulch materials on growth of green ash. J. Arbor. 9:711.

Montague, T. and R. Kjelgren. 2004. Energy balance of six common landscape surfaces and the influence of surface properties on gas exchange of four containerized tree species. Scientia Hort. 100:229-249.

Montague, T., C. McKenney, M. Maurer, and B. Winn. 2007. Influence of irrigation volume and mulch on establishment of select shrub species. Arboriculture and Urban Forestry 33:202-209.

Panshin, A.J. and C deZeeuw. 1980. Textbook of wood technology. 4th Ed McGraw-Hill, New York, NY.

Tseng, M., L. Wen-Rong, C. Hsieh, and Y. Kuo. 2007. Allelopathy on bark of downed logs of Chamaecyparis obtusa sieb. and Zucc. var. formosana (Hayata) Rehder. J. Chem. Ecol. 33:1283-1296.

Watson, G.W. 1988. Organic mulch and grass competition influence tree root development. J. Arbor. 14:200-203.

Watson, G.W. and G. Kupkowski. 1991. Effects of a deep layer of mulch on the soil environment and tree root growth. J. Arbor. 17:242-245. 